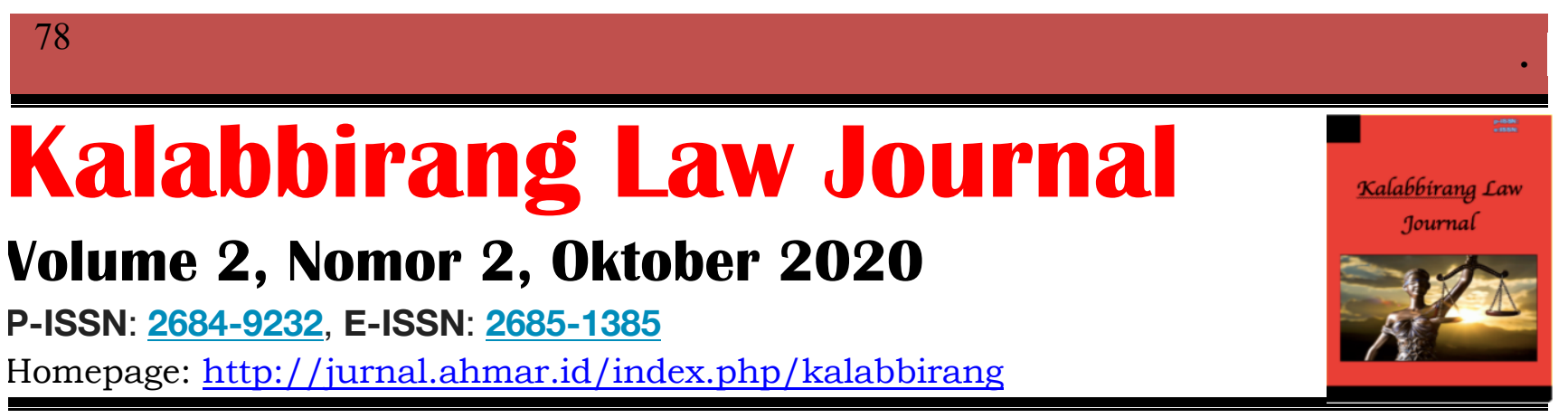

\title{
Efektifitas Penjatuhan Sanksi Pidana Terhadap Kejahatan Tindak Pidana Korupsi
}

\author{
Ikbal Sahardian ${ }^{1}$ Hambali Thalib ${ }^{2}$ \& Baharuddin Badaru ${ }^{3}$ \\ ${ }^{1}$ Magister Ilmu Hukum, Universitas Muslim Indonesia, Indonesia \\ ${ }^{2,3}$ Fakultas Hukum, Universitas Muslim Indonesia \\ Koresponden, Email: ikbal.sahardin@gmail.com
}

\begin{abstract}
ABSTRAK
Penelitin ini di latar belakangan oleh fenomena bahwa efektif tidaknya penjatuhan sanksi tindak pidana korupsi dikabupaten jayapura papua kebanyakan korupsi terjadi pada lingkup pemerintah maupun swasta tetapi kebanyakan juga korupsi yang terjadi di bidang pertanian terutama dampak negative pada sector perekonomian serta kehidupan pada petani sehingga menghambat kemajuan dan pertumbuhan disektor pertanian. Penelitian ini dilaksakan di kabupaten jayapura papua pada kantor polres jayapura, Kejaksaan Negeri Jayapura dan Pengadilan Negeri jayapura dengan alas an bahwa instansi yang terjadi di kabupaten jayapura selama tiga tahun terakhir. Hasil penelitian ini menukkan bahwa dalam waktu tiga tahun terakhir ini. Tingkat efektifitas penjatuhan sanksi tindak pidana korupsi mengalami peningkatan. Hal ini di sebabkan karena kekurangan kepekaan aparat penegak hokum dalam hal mencegah serta mengurangi terjadinya tindak pidana korupsi disamping itu pula kesadaran hukum dan oknum pemerintah sendiri yang melakukan tindak pidana korupsi yang seharusnya ia mengetahui hukum sebagai unsur pemerintah tetapi malah ia sendiri yang melakukan perbuatan korupsi. Padahal yang melakukan korupsi diancam dengan sanksi penjatuhan yang berat
\end{abstract}

Kata Kunci: Penjutan; Sanksi Pidana; Tindak Pidana Korupsi

\begin{abstract}
This study was in the background by the phenomenon that the effective absence of the rationing of corruption criminal sanctions in the district Jayapura Papua most corruption occurs in the scope of the government and private but most of the corruption in the field of agriculture, especially negative impact on the economic sector and life on the farmers, thereby inhibiting progress and growth of agricultural disetor. This research was established in Jayapura Papua District at the Jayapura Police Office, Jayapura state Attorney and the District Court of Jayapura with the base that the agency occurred in Jayapura district for the last three years. The results of this study have been inserted in the last three years. The level of effectiveness of criminal offence sanctions has increased. This has been caused by the Kekurangna sensitivity apparat the law enforcement in preventing and reducing the corruption of criminal acts besides the legal awareness and the Government itself who committed criminal acts of corruption that he should know the law as an element of the government but instead he himself doing corruption. In fact, corruption is threatened with heavy allotment sanctions
\end{abstract}




\section{PENDAHULUAN}

Korupsi di jayapura papua sudah merupakan patologi sosial (penyakit sosial) yang sangat berbahaya yang mengancam semua aspek kehidupan bermasyarakat, berbangsa dan bernegara. Korupsi telah mengakibatkan kerugian materil keuangan Negara yang sangat besar. Korupsi merupakan permasalahan universal yang dihadapi oleh seluruh negara dan masalah yang sulit untuk diberantas, hal ini tidak lain karena masalah korupsi bukan hanya berkaitan dengan permasalahan ekonomi semata melainkan juga terkait dengan permasalahan politik, kekuasaan dan penegakan hukum (Gunakarya, 2012).

Korupsi berarti penyelewengan atau penggelapan (uang negara atau perusahaan) dan sebagainya untuk kepentingan pribadi atau orang lain (Alam, 2017). Korupsi sendiri berasal dari bahasa latin corruption yang berasal dari kata kerja corrumpere yang bermakna busuk, rusak, menggoyahkan, memutar balik atau menyogok. Perbuatan korupsi selalu mengandung unsur ""penyelengan" atau dis-honest (ketidakjujuran) (Siregar, 2017). Korupsi pun sering dikaitkan dengan perilaku yang dilakukan oleh aparat pemerintah. Menurut Hungtinton (1968) bahwa korupsi adalah perilaku pejabat publik yang menyimpan dari norma-norma yang di terima oleh masyarakat, dan perilaku menyimpang ini ditujukan dalam rangka memenuhi kepentingan pribadi (Waluyo, 2017). Sedangkan transparency internasional (2010) sebagai salah satu organisasi masyarakat yang memerangi korupsi, mendenifisikan korupsi sebagai tindakan pejabat publik, baik politisi maupun pegawai negeri serta pihak lain yang terlibat dalam tindakan itu yang secara tidak wajar dan tidak legal menyalahgunakan kepercayaan publik yang dikuasakan kepada mereka untuk mendapatkan keuntungan sepihak (Setiyono, 2010).

Salah satu penyebab adalah rendahnya kualitas sumber daya manusia. Kualitas tersebut tidak hanya dari segi pengetahuan atau intelektual tetapi juga menyangkut kualitas moral dan kepribadiannya (Bunga, et.al. 2019). Rapuhnya moral dan rendahnya tingkat kejujuran dan aparat penyelenggara Negara menyebabkan terjadinya korupsi. Bentuk perampasan dan pengurasan keuangan negara demikian terjadi hampir di seluruh wilayah tanah air. Jika tidak berhasil memberantas korupsi, maka negara ini tidak akan mampu mengejar ketertinggalannya dibandingkan di negara lain. Karena korupsi membawa dampak negatif yang cukup luas dan dapat membawa negara ke jurang kehancuran (Setiawan \& fauzi, 2019).

Penyebab seseorang melakukan tindakan korupsi bervariasi dan keanekaragaman. Penyebab korupsi, yaitu ketiadaan kepemimpinan yang mempengaruhi tingkah laku menjinakkan korupsi, kelemahan pengajaran agama dan etika, konsumerisme, globalisasi, kurangnya pendidikan, kemiskinan, tidak adanya tindak hukuman yang keras, kelangkaan lingkungan yang subur untuk perilaku anti korupsi, struktur pemerintahan, dan perubahan radikal/transisi demokrasi (Mualifin, 2015).

Upaya pemberantasan korupsi telah mulai dilakukan oleh pemerintah. Haltersebut dapat dilihat dari banyaknya peraturan yang dikeluarkan sehubungan dengan permasalahan korupsi. Selain pembentukan peraturan perundang-undangan, pembentukan lembaga pengawasan baik yang bersifat internal maupun eksternal telah banyak dibentuk. Demikian pula halnya dengan kajian-kajian mengenai korupsi, oleh karena itu tulisan ini lebih ditujukan kepada peninjauan secara yuridis konseptual terhadap permasalahan korupsi (Paonganan, 2013). Untuk itu upaya pencegahan dan pemberantasan korupsi perlu semakin ditingkatkan dan diintensifkan dengan menjujung tinggi hak asasi manusia dan kepentingan masyarakat. Kejahatan korupsi merupakan kejahatan yang dilakukan secara sistematis dan terorganisasi serta dilakukan oleh orang-orang yang mempunyai kedudukan dan peranan penting dalam 
tatanan social masyarakat oleh karena itu kejahatan ini sering disebut white collar crime atau kejahatan kerah putih (Widiastuti, 2018). Menyadari kompleksnya permasalahan korupsi di tengah-tengah krisis multidimensional serta ancaman nyata yang pasti akan terjadi, yaitu dampak dari kejahatan ini. Maka tindak pidana korupsi dapat dikategorikan sebagai permasalahan yang harus dihadapi secara professional melalui keseimbangan langkahlangkah yang tegas dengan melibatkan semua potensi yang ada dalam masyarakat khususnya pemerintah atau aparat penegak hukum (Lubis, 2017).

Tindak pidana korupsi dapat terungkap setelah berlangsung dalam waktu yang lama. Umumnya tindak pidana korupsi melibatkan sekelompok orang yang saling menikmati keuntungan dari tindak pidana korupsi tersebut (Budiman, Thalib \& Ahmad, 2020). Kekhawatiran keterlibatannya sebagai tersangka, diantara sekelompok orang tersebut akan saling menutupi sehingga secara sadar tindak pidana korupsi itu dilakukan secara terorganisir dalam lingkup kerjanya (Yasser, 2019). Saat ada celah untuk melakukan tindak pidana korupsi, tidak semua individu akan melakukannya hal ini dikarenakan setiap individu memiliki karakteristik yang berbeda-beda dalam berperilaku. Karakteristik yang menetap ini disebut dengan kepribadian. Kepribadian yang dimiliki oleh individu akan menentukan bagaimana ia akan bertindak saat menghadapi suatu situasi tertentu.

Para perilaku tindak pidana korupsi di kabupaten jayapura papua akan dijatuhi hukuman penjara. Berdasarkan Undang-Undang No 20 tahun 2001 tentang perubahan Undang-undang No 31 tahun 1999 mengenai pemberatasan tindak pidana korupsi, hukuman penjatuhan sanksi hukuman yang diterima pelaku korupsi adalah hukuman penjara minimal 4 tahun. Hukuman ini diberikan dengan tujuan agar pelaku jera dan anggota masyarakat tidak ada yang mengulanginya (Rohromana, 2017).

Efektivitas merupakan unsur pokok untuk mencapai tujuan atau sasaran yang telah ditentukan di dalam setiap organisasi, kegiatan ataupun program. Disebut efektif apabila tercapai tujuan ataupun sasaran seperti yang ditentukan. Hal ini sesuai dengan pendapat $\mathrm{H}$ Emerson yang dikutip Soewarno Handayaningrat S (1994:16) yang menyatakan bahwa "“ Efektivitas adalah pengukuran dalam arti tercapainya tujuan yang telah ditentukan sebelumnya.

Dengan demikian untuk melakukan suatu tindak pidana korupsi diperlukan suatu pemikiran, rancangan agar dapat terlaksana perbuatan itu. Perilaku kejahatan korupsi pada dasarnya menyangkut penyelenggaran pelayanan umum dan lingkungan kerja yang mendatangkan sumber keuangan (Ridwan, Thalib \& Badaru, 2020). Karena itu korupsi terjadi melalui kelemahan sistem pengawasan dengan memanfaatkan situasi tertentu dari siklus pertumbuhan negara, perkembangan sistem sosial, dan keserasian struktur pemerintahan. Motif, penyebab atau pendorong bagi seseorang melakukan tindak pidana korupsi bermacam-macam. Tetapi secara umum dapat dirumuskan bahwa tindak pidana korupsi dilakukan dengan tujuan untuk mendapatkan keuntungan pribadi, keluarga, kelompok, golongan sendiri. Dengan mendasar motif keuntungan pribadi atau golongan maka dapat dipahami bahwa korupsi dapat terjadi dimana-mana dan kapan saja, Karena korupsi selalu terkait dengan motif yang ada pada setiap insane manusia untuk mendapatkan kepentingan pribadi atau golongan.

Sanksi terhadap pelanggaran tatanan hukum yang dapat dipaksakan dan dilaksanakan serta bersifat memaksa yang datangnya dari pemerintah merupakan perbedaan yang menonjol dengan pelanggaran terhadap tatanan lainnya. Pada hakikatnya sanksi bertujuan untuk 
memulihkan keseimbangan tatanan masyarakat yang telah ternganggu oleh pelanggaranpelanggaran kaidah dalam keadaan semula. Menurut kanter dan siantur tugas sanksi adalah: merupakan alat pemaksa atau pendorong atau jaminan agar norma hukum ditaati oleh setiap orang, merupakan akibat hukum bagi seseorang yang melanggar norma hukum.

Sanksi pidana adalah salah satu sarana paling efektif yang digunakan menanggulangi kejahatan, namun pidana bukan merupakan sarana satu- satunya sehingga apabila perlu digunakan kombinasi dengan upaya sosial lainnya, oleh karena itu perlu dikembangkan prinsip pidana ultimium remedium tidak menonjolkan sikap premium remedium (Wahyuni, 2016_. Dengan demikian, dapat dipahami bahwa yang dimaksudkan dengan sanksi dalam hal ini adalah sanksi hukum dalam arti sanksi negative yang unsur-unsurnya dapat dirumuskan sebagai reaksi terhadap akibat atau konsepkuensi terhadap pelanggaran atau penyimpanan kaidah sosial, baik kaidah sosial hukum maupun non hukum san merupakan kekuasaan atau alat kekuasaan untuk memaksakan ditaatinya kaidah tertentu.

\section{METODE PENELITIAN}

Penelitian ini merupakan gabungan dari dua penelitian yaitu penelitian normative dan penelitian hukum empiris karena di samping di perlukan bahan-bahan hukum juga di perlukan data empiris berupa data yang diperoleh langsung dari responden dilakukan juga wawancara secara langsung dilapangan. penelitian yang menjadi objek dalam penelitian ini adalah kabupaten jayapura papua. Populasi dalam penelitian ini adalah para penegak hukum yang berwenang dalam menangani tindak pidana korupsi yaitu polisi, jaksa, dan pengadilan yang dijadikan responden yang sejauh ini mengetahui kejahatan tindak pidana korupsi agar dapat dijatuhkan sanksi oleh para penegak hukum. ata yang berhasil dikumpulkan, baik data primer dan sekunder akan dianalisis secara kualitatif, kemudian disajikan dalam bentuk deskritif. Data kuantitatif mengenai efektifitas sanksi tindak pidana korupsi dan faktor penyebab terjadinya tindak pidana korupsi di kabupaten jayapura papua

\section{PEMBAHASAN}

\section{A. Efektivitas Penjatuhan Sanksi Pidana Terhadap Kejahatan Tindak Pidana Korupsi di Kabupaten Jayapura papua}

Tindak pidana korupsi merupakan tindak pidana yang tidak asing lagi dibicarakan dalam masyarakat hal ini disebabkan karena kasus korupsi semakin marak terjadi dari waktu ke waktu di samping itu pula tindak pidana korupsi adalah salah satu hambatan terburuk dalam pembangunan suatu bangsa serta hambatan terburuk dalam pertumbuhan disektor ekonomi dalam suatu negara. Istilah korupsi saat ini merupakan semua bentuk penyalahgunaan wewenang untuk memperkaya diri oleh pejabat pemerintah pusat maupun daerah dari semua jenjang, tetapi tindak pidana khususnya di kabupaten Jayapura biasanya dilakukan dan dinikmati oleh kalangan-kalangan pejabat sehingga perbuatan tersebut dapat menyengsarkan orang-orang miskin, sehingga yang miskin tetap miskin yang kaya tetap kaya. 
Untuk mengetahui tingkat perkembangan terakhir terjadinya tindak pidana korupsi di kabupaten Jayapura dari 3 tahun terakhir ini yakni dari tahun 2016 sampai 2018, penulis melakukan penelitian di kabupaten Jayapura tepatnya pada kantor polres Jayapura, kantor kejaksaan negeri jayapura, dan pengadilan negeri Jayapura. Untuk lebih jelasnya dapat dilihat pada tabel di bawah ini:

Tabel 1

Data Jumlah Tindak Pidana Korupsi di

Kantor Polres Kabupaten Jayapura Tahun 2016-2018

\begin{tabular}{|c|c|c|}
\hline Tahun & Pelaku & Persentase \\
\hline 2016 & 5 & $16 \%$ \\
\hline 2017 & 10 & $33 \%$ \\
\hline 2018 & 15 & $50 \%$ \\
\hline Jumlah & 30 & $100 \%$ \\
\hline \multicolumn{2}{|c|}{ Sumber Data: Kantor Polres Kabupaten Jayapura, tahun 2019 }
\end{tabular}

Tabel di atas menunjukkan tahun 2016 pelaku 5 (lima) orang dengan persentase $16 \%$ tetapi pada tahun 2017 mengalami peningkatan dari tahun sebelumnya dengan persentase 33\% hal ini dapat dibuktikan dengan hasil wawancara dengan bapak Jeffry selaku penyidik tindak pidana korupsi (November 2019) bahwa Bahwa pada tahun 2017 kasus korupsi mengalami peningkatan dari tahun 2016, hal ini disebabkan karena faktor keserakahan berkaitan dengan adanya perilaku serakah yang secara potensial dalam diri perilaku sehingga perilaku sehingga perilaku kurang menyadari akan perbuatan yang telah merugikan keuangan negara, dengan adanya perbuatan tersebut patut untuk ditindak lanjuti."

Menurut bapak jeffry kasus yang terjadi pada tahun 2017 adalah kasus penyalahgunaan uang negara pengadaan paket berupa pembangunan dermaga ravenirara senilai 70 milyar yang melibatkan 10 pelaku dengan tersangka mustika wati. Sedangkan menurut bapak Anas selaku penyidik tindak pidana korupsi (November 2019) menyatakan bahwa Pelaku yang ingin cepat kaya dengan cara yang haram, tidak ada kesadaran bermasyarakat, dan kesempatan untuk melakukan korupsi sehingga perbuatan tersebut tidak disadarinya adalah perbuatan yang merugikan keuangan negara, walaupun perbuatan tersebut telah melanggar norma-norma hukum tetapi ada kesempatan kepada pelaku perbuatan tetap dilakukan karena keinginan untuk cepat meningkat tetapi dilakukan dengan cara pintas yaitu melakukan perbuatan korupsi yang melanggar hokum

Tahun 2018 mengalami peningkatan yang sangat dratis yaitu dari 10 pelaku menjadi 15 pelaku dengan persentase $50 \%$, hal ini juga disebabkan oleh beberapa faktor, sebagaimana 
dari hasil wawancara oleh bapak jeffry, selaku penyidik tindak pidana korupsi (November 2019) bahwa Besarnya pendapatan dari korupsi, besar/tingginya tingkat hukuman jika tertangkap, dan kemungkinan (probabilitas) tertangkap. Pemahaman terhadap mekanisme pengaruh dari faktor-faktor tersebut dipercaya dapat membantu pengambil kebijakan(pada berbagai tingkatan pemerintah/institusi) dalam menerapkan strategi penanganan korupsi. Korupsi merupakan penyalahgunaan hak dan kepentingan publik untuk kepentingan/keuntungan pribadi mempermasalahkan penyalahgunaan hak dan kepentingan publik oleh pejabat negara/pegawai negeri saja tetapi juga oleh masyarakat. Ukurannya adalah hak dan kepentingan publik yang penyalahgunaannya dapat dilakukan oleh pejabat negara atau pegawai negeri atau oleh masyarakat biasa. Penyalahgunaan hak dan kepentingan publik seperti penyalahgunaan APBN/APBD oleh pejabat negara atau pegawai negeri, penggunaan asset publik oleh pejabat negara atau pegawai negeri atau masyarakat biasa, atau penyalahgunaan wewenang yang mengakibatkan kerugian publik seperti keuangan publik atau hak publik lainnya akan dikategorikan perbuatan korupsi.

Sedangkan dari hasil wawancara oleh bapak Anas selaku penyidik tindak pidana korupsi (November 2019) mengatakan bahwa Peningkatan globalisasi sangat berpengaruh terhadap tingkat terjadinya tindak pidana korupsi. Artinya beberapa faktor lain juga sangat berpengaruh terhadap perubahan tingkat korupsi di kabupaten Jayapura antara lain kekuatan hukum yang tegas serta sumber daya manusia (SDM), adalah bermoral baik yang melakukan korupsi disebabkan karena orang yang melakukan korupsi.”

Melihat dari data tabel 1 di atas pada jumlah pelaku tindak pidana korupsi di kantor polres Kabupaten Jayapura tahun 2016-2018 tersebut, terlihat bahwa jumlah tindak pidana korupsi yang terjadi mengalami peningkatan yang cukup dratis. Sedangkan dari kantor kejaksaan pelaku tindak pidana korupsi sebanyak 25 pelaku kejahatan tindak pidana korupsi, yang dimana penuliS telah melakukan penelitian di Kabupaten Jayapura tepatnya pada kantor Kejaksaan Negeri Jayapura. Untuk lebih jelasnya dapat dilihat pada tabel di bawah ini:

Tabel 2

Data Jumlah Tindak Pidana Korupsi di Kantor Kejaksaan

Kabupaten Jayapura Tahun 2016-2018

\begin{tabular}{|c|c|c|}
\hline Tahun & Pelaku & Persentase \\
\hline $\mathbf{2 0 1 6}$ & 4 & $16 \%$ \\
\hline $\mathbf{2 0 1 7}$ & 9 & $36 \%$ \\
\hline $\mathbf{2 0 1 8}$ & 12 & $48 \%$ \\
\hline Jumlah & 25 & $100 \%$ \\
\hline
\end{tabular}

Sumber Data: Kantor Kejaksaan Negeń Jayapura. Tahun 2019 
Tabel diatas menunjukkan tahun 2016 pelaku 4 (empat) orang dengan persentase 16\% tetapi pada tahun 2017 mengalami peningkatan dari tahun sebelumnya dengan persentase 36\%. Hal ini dapat dibuktikan dengan hasil wawancara dari bapak Renaldy Palyama,SH selaku Kepala Seksi Tindak Pidana khusus (November 2019), mengatakan bahwa: Tradisi untuk menambah penghasilan yang kurang dari pejabat pemerintah dengan upeti atau suap dan dimana berbagai macam korupsi dianggap biasa, tidak dianggap bertentangan dengan moral, sehingga orang berlomba untuk korupsi, sehingga perbuatan korupsi dianggap hal yang biasa dan mudah menjadi lumrah.”

Menurut ibu lusi rumbino, SH selaku jaksa tipikor (November 2019), mengatakan bahwa Tidak dapat menolak suapan dan korupsi, kecuali menganggap telah berlebihan harta dan kekayaannya. Manakala orang menghargai aturan- aturan resmi dan tujuan organisasi pemerintah. Tahun 2018 kasus korupsi semakin meningkat sebagaimana hasil wawancara dengan bapak Renaldy Palyama, SH selaku kepala seksi tindak pidana khusus (November 2019), mengatakan bahwa: Peningkatan kasus korupsi disebabkan karena kurangnya penghasilan sehari-hari sehingga si pelaku melakukan perbuatan yang tidak sesuai dengan keinginannya seperti melakukan pengambilan uang Negara.

Rendahnya pendapatan penyelenggaran negara, pendapatan yang diperolehharus mampu memenuhi kebutuhan penyelenggara negara, mampu mendorong untuk berprestasi dan memberikan pelayanan terbaik bagi masyarakat. Melihat tabel 2 diatas pada data jumlah pelaku tindak pidana korupsi di kantor kejaksaan negeri Jayapura mulai dari tahun 2016 sampai dengan tahun 2018, terlihat jelas bahwa jumlah pelaku tindak pidana korupsi mengalami peningkatan yang sangat drastis.

Dari kantor pengadilan negeri Jayapura pelaku kejahatan tindak pidana korupsi, yang mana penulis telah melakukan penelitian di kabupaten Jayapura tepatnya di kantor pengadilan negeri Jayapura. Untuk lebih jelasnya dapat dilihat pada tabel halaman selanjutnya:

Tabel 3

Data Jumlah tindak pidana korupsi di kantor pengadilan negeri

Jayapura tahun 2016-2018

\begin{tabular}{|c|c|c|}
\hline Tahun & Pelaku & Persentase \\
\hline $\mathbf{2 0 1 6}$ & 4 & $16 \%$ \\
\hline $\mathbf{2 0 1 7}$ & 9 & $36 \%$ \\
\hline $\mathbf{2 0 1 8}$ & 12 & $48 \%$ \\
\hline Jumlah & 25 & $100 \%$ \\
\hline
\end{tabular}

Sumber Data: kantor pengadilan negeri Jayapura tahun 2019 
Memperhatikan Pasal 2 ayat (1) Undang-Undang Nomor 31 Tahun 1999 tentang pemberantasan Tindak Pidana Korupsi Jo pasal 18 Undang- Undang Nomor 31 Tahun 1999 sebagaimana telah diubah dan ditambah dengan Undang-Undang Nomor Tahun 2001 tentang pemberantasan Tindak Pidana Korupsi Jo pasal 55 ayat (1) ke-1 KUHP, UndangUndang Nomor 46 Tahun 2009 tentang Pengadilan Tindak Pidana Korupsi, UndangUndang Nomor 8 Tahun 1981 tentang Hukum Acara Pidana serta peraturan perundangundangan lain bersangkutan dengan perkara ini.

MENGADILI:

1. Menyatakan terdakwa Mustikawati tersebut diatas terbukti secara sah dan menyatakan bersalah melakukan tindak pidana korupsi secara bersama-sama sebagaimana dalam dakwaan alternative kesatu

2. Menjatuhkan pidana kepada terdakwa oleh karena itu dengan pidana penjara selama 4 Tahun dan denda sejumlah Rp. 200.000.00o,oo (dua ratus juta rupiah) dengan ketentuan apabila denda tersebut tidak dibayar diganti dengan pidana kurungan selama 7 bulan;

3. Menghukum terdakwa untuk membayar uang pengganti sejumlah Rp. 1.476.914.643,oo (satu milyar empat ratus tujuh puluh enam juta Sembilan ratus empat belas ribu enam ratus empat puluh tiga rupiah) paling lama dalam waktu satu bulan sesudah putusan ini berkekuatan hukum tetap, jika tidak membayar maka harta bendanya disita dan dilelang oleh Jaksa untuk menutupi uang pengganti tersebut dengan ketentuan apabila terpidana tidak mempunyai harta benda yang mencukupi maka dipidana dengan pidana penjara selama 2 Tahun;

4. Menetapkan masa penangkapan dan penahanan yang telah dijalani terdakwa dikuranngkan seluruhnya dari pidana yang dijatuhkan;

5. Menetapkanterdakwatetapditahan;

6. Membebankan kepada terdakwa membayar biaya perkara sejumlah Rp. 10.00o,oo (sepuluh ribu rupiah).

Demikianlah diputuskan dalam siding permusyawaratn Majelis Hakim Pengadilan Tindak Pidana Korupsi pada Pengadilan Negeri Jayapura, pada hari senin, tanggal 1o September 2018 oleh Maria M.Sitanggang,SH.MH selaku Hakim Ketua, masing-masing sebagai Hakim Anggota yang d tunjuk berdasarkan surat penetapan Ketua Pengadilan Negeri Jayapura Nomor 21/Pid.Sus-TPK/2018/PN-Jap tanggal 26 April 2018 dan diucapkan dalam siding terbuka untuk umum pada hari kamis tanggal 13 September 2018 oleh Hakim Ketua dengan didampingi para Hakim Anggota tersebut dibantu oleh Roida Sitorus, Panitera Pengganti Pengadilan Tindak Pidana Korupsi pada Pengadilan Negeri Jayapura serta dihadiri oleh Johannes H. Siregar, SH.MH Penuntut Umum pada Kejaksaan Negeri Jayapura dan terdakwa.

Berkaitan dengan hal tersebut, menurut Ibu Elisa B Titahena, SH selaku Hakim Tindak Pidana Korupsi bahwa: 
"faktor ekonomi memang sangat mempengaruhi orang melakukan tindak pidana korupsi, karena adanya pendapatan yang tidak sebanding dengan kebutuhan sehingga menyebabkan melakukan tindak pidana korupsi, disebabkan karena adanya keinginan untuk hidup mewah, sedangkan pendapatan mencukupi."

Beliau membenarkan adanya kasus Tindak Pidana Korupsi yang terjadi pada bulan April 2016 dan putusan pengadilan di tahun 2018 oleh terdakwa Mustikawati selaku direktur CV.samusti raya.

\section{a. Iman dan mental}

Lemahnya Iman seseorang adalah salah satu faktor untuk melakukan tindak pidana korupsi, karena pelaku tindak pidana korupsi menganggap bahwa uang adalah segalanya maka dengan mudah akan terjerumus untuk melakukan tindak pidana korupsi, tanpa memikirkan akibat yang akan ditimbulkan.

Faktor mental yang tidak sehat lebih dominan untuk mendorong terjadinya perbuatan tindak pidana korupsi, sebab sekali ppun faktor-faktor lainnya itu terdapat pada diri seseorang akan tetapi apabila ia bermental sehat maka tidak akan mudah melakukan tindak pidana korupsi. Sehubungan dengan hal ini, penulis melakukan wawancara dengan bapak Bernard Akasian,SH.MH selaku Hakim pada pengadilan Negeri Jayapura menyatakan. Penyebab Tindak Pidana Korupsi, adanya mental dan akhlak yang tidak baik, sehingga orang tersebut melakukan tindak pidana korupsi yang tentu saja merusak sendi-sendi moral, sehingga nilainilai yang sudah tertanam dihati masyarakat, bahwa perbuatan korupsi adalah perbuatan yang jahat di hati masyarakat, sehingga orang yang rusak mentalnya dapat saja melakukan tindak pidana korupsi. Dari pihak kantor kejaksaan, penulis melakukan wawancara kepada bapak Renaldy Palyama,SH selaku Kepala Seksi Tindak Pidana Khusus menyatakan:

Bahwa dengan adanya akhlak dan mental yang tidak terpuji, orang dapat saja melakukan tindak pidana korupsi, salah satu juga pemicunya adalah dengan adanya akhlak yang buruk ia dapat melakukan tindak pidana korupsi, disamping itu rasa malu untuk melakukan tindak pidana korupsi sudah mulai hilang atau pudar sehingga orang melakukan tindak pidana korupsi, sebab perbuatan korupsi adalah perbuatan yang tercela dimata pemerintah dan masyarakat."

\section{b. Lemahnya birokrasi sistem pengawasan (Aparat Penegak Hukum)}

Salah satu faktor penyebab terjadinya tindak pidana korupsi di kabupaten Jayapura adalah karena tidak berjalannya atau tidak efektifnya mekanisme organisasi dan fungsi manajemen dalam suatu pemerintahan. Fungsi manajemen yang dimaksud adalah masing-masing perencanaan yang telah dibuat dengan keliru atau sengaja dimanupulasikan, fungsi pelaksanaan yang menyimpang dari semestinya karena sejak semula didasarkan pada perencanaan yang salah dan fungsi pelaksanaan yang dilaksanakan semaksimal mungkin.

Lemahnya mekanisme organisasi akan menjadi peluang bahkan menjadi pendorong untuk melakukan tindak pidana korupsi. Dengan sistem pemerintahan yang tidak disiplin, maka 
akan memberikan kesempatan kepada pegawai negeri untuk melakukan tindak pidana korupsi. Sehubungan dengan hal itu wawancara dengan ibu chita yohana,SH.MH selaku Hakim pada kantor Pengadilan Negeri Jayapura menyatakan lemahnya birokrasi sehingga dengan kurang pengawasan di bidang birokrasi seseorang dapat memanifulasi data yang seharusnya, sehingga perbuatan tersebut adalah perbuatan tindak pidana korupsi dengan lemahnya pengawasan yang dilakukan di bidang bikrokrasi dengan adanya kesempatan yang ada dapat melakukan korupsi. Kerusakan dan kehacuran bangsa dalam bidang saat ini yang disebabkan oleh praktik korupsi. Hal ini dapat dilihat dari terhambatnya proses pembangunan dari berbagai sektor yang menurunkan citra dan martabak bangsa, meningkatkan kemiskinan dan pengangguran.

Oleh karena itu, pencegahan korupsi harus dilakukan sejak dini, dengan melihat masa lalu dan berfikir ke depan karena pencegahan korupsi bukan hanya semata-mata slogan kehidupan akan tetapi upaya tersebut dilakukan untuk mencegah terjadinya tindak pidana korupsi serta bagaimana cara masyarakat dan pemerintah dapat bekerja sama dalam merubah perilaku para koruptor untuk tidak lagimengulangi perbuatan tersebut ataupun mencegah terjadinya tindak pidana korupsi.

Untuk mencegah dan menanggulangi terjadinya tindak pidana korupsi di kabupaten jayapura maka diperlukan upaya-upaya baik berupa preventif maupun reprensif.

1. Upaya penanggulangan secara preventif

Tindakan preventif adalah bentuk pencegahan yang untuk mengurangi terjadinya tindak pidana korupsi. Memberantas suatu kejahatan agar tidak terjadi lagi adalah suatu hal yang tidak mungkin, akan tetapi usaha untuk menekan dan mencegah seharusnya dilakukan secara terus menerus dan secara berkesinambungan sehingga kejahatan dalam masyarakat dapat dikurangi.

Adapun upaya penanggulangan secara preventif adalah sebagai berikut ;

a. meningkatkan kinerja para pihak yang berwenang dalam hal mengurangi tindak pidana korupsi dalam hal ini, aparat penegak hukum seperti kepolisian, jaksa dan pihak pengadilan.

b. Mengadakan penuluhan agama,dan penyuluhanhukum

c. Lemahnya moral seseorang merupakan penyebab terjadinya tindak pidana korupsi, karena para koruptor lebih mementingkan kehidupan duniawan ketimbang kehidupan akhirat, sehingga para koruptor tidak memperdulikan lagi dampak yang akan terjadi dihari dikemudian, para koruptor hanya memikirkan bagaimana memperoleh banyak uang. Padahal perbuatan tersebut hanyalah kebahagian sesaat. Oleh karena itu pemerintah harus memberikan penyuluhan hukum dan agama kepada seluruh masyarakat khusunya para pegawai ataupun para pejabat seta para koruptor agar tidak lagi melakukan tindak pidana korupsi. 
d. Melakukan penangkapan dan penahanan terhadap pelaku tindak pidana korupsi, bahwa setiap perbuatan yang terjadi dalam masyarakat termasuk tindak pidana korupsi, sebaiknya dilaporkan ke pihak yang berwajib atau aparat hukum dan para hukum harus melakukan penangkapan ataupun penahanan kepada pelaku tanpa melihat status seseorang.

e. Meningkatkan kesadaran hukum dan dukungan masyarakat dukungan dan kesadaran hukum masyarakat sangat dibutuhkan dalam mengurangi terjadinya tindak pidana korupsi, karena kesadaran hukum merupakan hal yang penting dalam mengurangi terjadinya kejahatan dalam masyarakat karena walaupun banyak kegiatan yang dilakukan oleh pemerintah baik melakukan penyuluhan hukum dan agama, akan tetapi kesadaran hukum masyarakat masih sangat minim maka akan sulit memberantas kejahatan termasuk tindak pidana korupsi.

Sesungguhnya peranan masyarakat sangat dibutuhkan, jika terjadi penyimpangan dalam masyarakat maka segera melaporkan kepada pihak yang berwajib. Disisi lain aparat hukum harus memperhatikan laporan dari masyarakat dan diperhatikan dengan sungguh-sungguh dan ditangani dengan cepat agar tidak terjadi inpretasi yang negative dari masyarakat yang pada umumnya masyarakat enggan melaporkan kejahatan yang terjadi karena aparat penegak hukum kurang merespon dalam menerima laporan dari masyarakat.

2. Upaya penanggulangan secarare prensif

Selain penanggulangan secara reprensif yang dilakukan untuk mencegah terjadinya tindak pidana korupsi di kabupaten Jayapura, upaya yang lain yang di tempuh adalah upaya represif yaitu melakukan tindakan- tindakan hukum terhadap perilaku tindak pidana korupsi dalam batas-batas kewajaran dalam mengurangi tindak pidana korupsi. Usaha penanggulangan tindak pidana korupsi yang bersifat reprensif yang dilakukan aparat penegak hukum di kabupaten Jayapura adalah sebagai berikut:

a. Mengefektifkan pemberlakuan segala bentuk peraturan perundang- undangan khususnya Undang-Undang No. 20 Tahun 2001 tentang pemberantasan tindak pidana korupsi;

b. Pengusutandanpenyidikan;

c. Pembentukan team pemberantasan tindak pidana korupsi. Pemberian sanksi hukuman yang maksimal kepada koruptor dalam menjatuhkan pidana terhadap pelaku, harus benar-benar adil, tanpa pandang bulu dan sesuai dengan aturan yang berlaku sebagaimana yang diatur dalam Undang-Undang No. 31 Tahun 1999 Jo Undang-Undang No. 20 tahun 2001 tentang tindak pidana korupsi. Namun penerapannya di kabupaten Jayapura belum optimal dalam hal ini penjatuhan sanksi pidana terhadap tindak pidana korupsi.

Data di atas menunjukkan bahwa bagaimana juga budaya hukum berpengaruh di masyarakat (90\%), responden yang menyatakan kurang berpengaruh (3.33\%), dan (6.67\%) yang menyatakan tidak berpengaruh. Bagi masyarakat yang melakukan proses peralihan tanah 
melalui perjanjian dibawah tangan agar memberitahukan kepada pemerintah daerah setempat untuk melakukan pencatatan atau pembukuan agar memperlancar proses pendaftaran tanah. Menurut Soerjono Soekanto (1983:45), budaya hukum pada dasarnya mencakup nilai-nilai yang mendasari hukum yang berlaku, nilai-nilai yang merupakan konsepsi-konsepsi abstrak mengenai apa yang dianggap baik sehingga dianut dan apa yang dianggap buruk sehingga dihindari

\section{KESIMPULAN}

Penegakan hukum melalui pendekatan restorative justice dalam praktik telah berjalan, tidak Penerapan sanksi pidana dalam masyarakat yang belum optimal, serta aparat hukum masih lengah melaksanakan tugas dan tanggungjawabnya dalam mengurangi kasus kejahatan tindak pidana korupsi yang terjadi di Kabupaten Jayapura. Yang mempengaruhi Penjatuhan sanksi pidana korupsi terdapat beberapa faktor penyebab terjadinya tindak pidana korupsi di Kabupaten Jayapura, antara lain Faktor kekuasaan merupakan kesempatan yang dimiliki oleh koruptor untuk menggunakan uang negara demi kepentingan perorangan. Faktor ekonomi, mengingat pola hidup semakin modern salah satu penyebab terjadinya tindak pidana korupsi karena sudah menjadi tuntutan hidup masyarakat. Faktor mental/moral yang tidak sehat lebih dominan untuk mendorong terjadinya perbuatan korupsi. Faktor Hukum yaitu lemahnya mekanisme organisasi akan menjadi peluang bahkan akan menjadi pendorong untuk melakukan tindak pidana korupsi.

\section{DAFTAR PUSTAKA}

Alam, S. (2017). Tinjauan Yuridis Atas Tindak Pidana Korupsi Dalam Praktek di Indonesia. Jurnal Hukum Replik, 5(2), 157-171.

Budiman, B., Thalib, H. ., \& Ahmad, K. . (2020). Pembuktian Perkara Tindak Pidana Korupsi Yang Diputus Bebas: Studi Pengadilan Negeri Makassar. Journal of Lex Philosophy (JLP), 1(1), 1-19

Bunga, M., Maroa, M. D., Arief, A., \& Djanggih, H. (2019). Urgensi Peran Serta Masyarakat Dalam Upaya Pencegahan Dan Pemberantasan Tindak Pidana Korupsi. Law Reform, 15(1), 85-97.

Gunakaya, W. (2012). Wanprestasi Sebagai Kualifikasi Tidak Dipenuhinya Kewajiban Hukum Yang Menimbulkan Kerugian Keuangan Negara. Jurnal Yudisial, 5(2), 189-223.

Lubis, E. Z. (2017). Dampak Melawan Hukum Dalam Tindak Pidana Korupsi. Jurnal Administrasi Publik (Public Administration Journal), 7(2), 107-116.

Muallifin, M. D. A. (2015). Problematika Dan Pemberantasan Korupsi Di Indonesia. Ahkam: Jurnal Hukum Islam, 3(2), 311-325.

Paonganan, R. T. (2013). Kewenangan Penuntutan Komisi Pemberantasan Korupsi dan Kejaksaan dalam Penanganan Tindak Pidana Korupsi di Indonesia. Lex Crimen, 2(1), 21-36.

Ridwan, R., Thalib, H., \& Baharuddin, H. (2020). Fungsi Kepolisian Dalam Penyidikan Tindak Pidana Korupsi Pengadaan Barang Dan Jasa: Studi Polres Pelabuhan Makassar. Journal of Lex Theory (JLT), 1(1), 116-128 
Rohromana, B. (2017). Pidana Pembayaran Uang Pengganti Sebagai Pidana Tambahan dalam Tindak Pidana Korupsi. Jurnal Hukum PRIORIS, 6(1), 44-65

Setiawan, A., \& Fauzi, E. A. (2019). Etika Kepemimpinan Politik Dalam Penyelenggaraan Pemerintahan Indonesia. Jurnal Pemerintahan dan Kebijakan (JPK), 1(1), 1-12.

Setiyono, B. (2010). Korupsi, Transisi Demokrasi \& Peran Organisasi Civil Society (CSO): Sebuah Tinjauan Teoritis. POLITIKA-Jurnal Ilmu Politik, 1(1), 4-21.

Siregar, S. L. (2017). The Literature Review: Corruption Behaviour and Causes. Fundamental Management Journal, 2(1), 47-56.

Wahyuni, F. (2016). Sanksi Pidana Pemerkosaan Terhadap Anak Menurut Hukum Pidana Positif dan Hukum Pidana Islam. Media Hukum, 23(1), 95-109.

Waluyo, B. (2017). Optimalisasi pemberantasan korupsi di indonesia. Jurnal Yuridis, 1(2), 169-162.

Widiastuti, T. W. (2012). Korupsi dan Upaya Pemberantasannya. Wacana Hukum, 8(2), 107118

Yasser, B. M. (2019). Pengujian Unsur Penyalahgunaan Wewenang Pada Peradilan Tata Usaha Negara Dalam Kaitannya Dengan Tindak Pidana Korupsi. Soumatera Law Review, 2(1), 1-24. 